\title{
ACCUMULATION OF SOME HEAVY METALS IN THE BEES' BODY, DEPENDING ON HUMAN IMPACT
}

\author{
Gliga Olesea \\ Institute of Zoology of MECR, Chisinau city, Republic of Moldova \\ oleseagliga@gmail.com
}

https://doi.org/10.53937/9789975315975.42

Pollutants, such as heavy metals, are emitted in air, water and soil by anthropogenic polluting sources and natural phenomena, being accumulated by flora and fauna of those ecosystems. More than 20 years honey bees (Apis mellifera) are used as indicators of ecosystems' pollution. During active movement the heavy metals enter in the bees' body through the air and are absorbed through the surface of the porous body and breathing. The content of pollutants in the bees body depends on many factors: the extent and the location of the apiary, the ecological status of the area, the methodology of increasing bee families, working bees age, physiological status, health of bee colonies etc. There are several works proving the accumulation of heavy metals in the bees fat and rectum. The heavy metals present in the atmosphere can be stored on the bees' body brushes, in pollen or can be absorbed with nectar, mildew or water. Excessive levels of $\mathrm{Pb}$ (12-50 mg per head/bee), Cd (6-30 $\mathrm{mg}$ per head/bee) and Cu (50 to $250 \mathrm{mg}$ per head/bee) are important reasons of regression and even the disappearance of species $A$. mellifera.

The aim of this paper was to determine the residues of heavy metals such as $\mathrm{Pb}, \mathrm{Cd}$ and $\mathrm{Cu}$ in the bees' body depending on human impact. The researches were carried out in the central part of the Republic of Moldova. 4 research areas have been selected (forest, agricultural, transport and industrial area) with different anthropogenic impact, where 12 experimental bee families were placed. The quantitative analysis was performed using atomic absorption spectrometry. 
It was found, that the honey bee responds to environmental changes by variation of $\mathrm{Pb}, \mathrm{Cd}$ and $\mathrm{Cu}$ concentrations in its body in dependence on bee families' location. Among the studied metals the highest residues concentrations in all areas in the bees' body was $\mathrm{Cu}$, followed by $\mathrm{Pb}$ and $\mathrm{Cd}$. The average concentrations of $\mathrm{Pb}$ in the bees body from the industrial and the transport areas have been significantly higher compared with those from forest area, respectively with $0.797 \mathrm{mg} / \mathrm{kg}\left(\mathrm{t}_{\mathrm{d}}=7.73 ; \mathrm{P}<\right.$ $0.001)$ and $0.666 \mathrm{mg} / \mathrm{kg}\left(t_{d}=8.12 ; P<0.001\right)$. Also, the average content of $\mathrm{Cd}$ in the bees body from industrial and transport areas was significantly higher compared with those from the forest area, respectively with $0.157 \mathrm{mg} / \mathrm{kg}\left(\mathrm{t}_{d}=6.04 ; \mathrm{P}<0.001\right)$ and $0.089 \mathrm{mg}\left(\mathrm{t}_{\mathrm{d}}=8.09 ; \mathrm{P}<0.001\right)$. Regarding the average content of $\mathrm{Cu}$ in the bees body from the agricultural areas, also was significantly higher than those from forest area with $3.52 \mathrm{mg} / \mathrm{kg}\left(\mathrm{t}_{\mathrm{d}}=10.66 ; \mathrm{P}<0.001\right)$. In all investigated areas, the heavy metals concentrations in the bees' body have been much lower than the noxious dose for bees.

Investigations were performed under the project 15.817.02.12F. 